\title{
The Intensive Reading Course of Cultural Introduction in The Foundation Stage of College English
}

\author{
Li Meijing \\ Foreign Language Department \\ Jilin Business and Technology College \\ Changchun, China
}

\begin{abstract}
University "Intensive English" is a very comprehensive curriculum. In this course, teachers teach different aspects of imported word, text and communication related cultural environment, thus improving students 'intercultural communicative competence, improve cultural knowledge and cultural awareness of students, and deepening teachers' understanding of foreign language teaching. From the relationship between language and culture, this paper analyzes the important role of culture in college English teaching and intensive courses in the specific content of the imported culture, and cultural introduction intensive English classes throughout the university-related issues for analysis.
\end{abstract}

Keywords-Foreign language teaching; cultural introduction; College English reading

\section{ANALYSIS OF THE RELATIONSHIP BETWEEN LANGUAGE AND CUlTuRE}

It has long been recognized that language is an essential and important part of culture, with the essential and irreplaceable cultural influence[1].There is a close relationship between language and culture, which is a not self-evident axiom, if we briefly review what a century in the field of linguistics in the past, you can find more evidence to support this view. We must admit that, since the beginning of eighteenth Century, a study of language in essence is either historical comparison, or formal structure. However, some new changes appeared at the beginning of twentieth Century. Both in the UK and in North American language studies began to turn human, this new tradition is characterized with the study of language. In the context of social culture, in the UK, Malinowski and Firth is a pioneer in the movement, and in North America and the parallel but independent tradition, boas, Sapir and Whorf nature is its representative. Because of their creative and tireless efforts, many important and innovative research areas in the field of language and cultural relations the creative work can be accomplished.

Anthropologist Malinowski in Trobriand Island on the east coast of New Guinea to fieldwork observed in the primitive culture, the meaning of a word in a large extent dependent on the context, or relies on to life in the real language environment. Firth is the leader of the later London School, by Malinowski human linguistic view, also fully aware of the importance of context in the study of language use in trying to build a model to illustrate the use of language and other factors closely related to it. Based on the above understanding, he proposed his situational context theory, which can be summarized as follows:

\section{A. Participants related features: characters, personality}

1) Speech acts of the participants

2) Nonverbal behavior of the participants

\section{B. About things}

Furse pointed out that the use of language in language creativity and diversity here. Wolf Benjamin, an important figure in American linguistics, has been interested in language, anthropology and Archaeology since the beginning of twentieth Century[2].Later, he dropped in on some of Sapir's linguistics courses at the Yale University, and in his own. A special resonance is found between Sapir and the idea. This experience and his study of the Indian Hopi language made him a unique understanding of the theory of linguistic relativity, and eventually formed a well-known Wolf Sapir hypothesis. This hypothesis can be formulated as: our language has shaped our thinking patterns, and accordingly, different language expressions determine the different ways we know the world. Analysis of this view found that language can determine our way of thinking, and the similarity between languages is relative. The greater the structural differences is, the more different the understanding of the world is. The relationship between language and culture is not only theoretically important, but also very important in practice.

\section{The IMPORTANCE of Cultural Import College English Teaching}

In the present situation to see, there are some problems in the current situation of College English teaching, the teaching effect is not satisfactory. College English are as a compulsory course for non-English Majors in grade one and two, occupied many classes, students and teachers also paid a great deal of time and effort, but English communicative ability of students is not satisfactory. Also with the situation also leads, although the students learn English for many years, which is number of many of the English level test, but they still cannot properly 
communicate with foreigners, often make this or that kind of cultural errors, the ability of society culture is far below their language ability, and social and cultural knowledge deficiency can also become an obstacle to the development of listening, speaking, reading, writing and translation ability. Analysis of the causes of the above problems, the reason is our long-term in the form of language teaching focus, examination oriented teaching objective, and then import and ignore the cultural factors in language teaching[3].

The language of different nationalities is different, and inevitably reflects the cultural differences between different nations. Language is a mirror of the national culture, the historical tradition, social system, values, way of life and way of thinking of any nation. Language educators in the "language teaching: the scientific approach", said: "we do not grasp the cultural background can't be a good language. Language is a part of culture, so it is impossible to learn a language without understanding its cultural patterns and rules. "The College English Teaching Syllabus (Revised Edition) stipulates:" College English teaching should also help students to broaden their horizons, expand knowledge, deepen their understanding of the world, learn and absorb the essence of the world culture, improve cultural literacy. Culture and language are closely related, and certain cultural background knowledge helps to improve the ability of language application. The knowledge of language can only guide people to express the correct sentences, while the pragmatic competence guides the people to express the proper and appropriate words. Therefore, in College English teaching and strengthening the background of western culture and cultivating students' intercultural communicative competence are very important and necessary, which further explains that we should strengthen cultural teaching and cultivate students' pragmatic competence.

\section{ANAlysis OF UnIVERSITY INTENSIVE COURSE CULTURE IMPORT CONTENT}

Culture is dynamic and compatible, so the introduction of culture should be open and developmental. In the university, English intensive reading course is a professional basic course for English majors. In the classroom teachers should fully take into account the students' listening, speaking, reading, writing and translating skills. In order to achieve the project, teachers in the classroom can import related words and expressions of culture, discourse and the cultural and communicative environment. Related culture and the content have been fully penetrated in the four links of the teaching process.

\section{A. Culture related to words}

For the primary stage of the students, the teacher's teaching content can be side Focusing on the terms of the import, the import of words are also from many aspects. It contains greetings, address, euphemism, taboo and language symbols in the deep culture. For example: in the Modern University of Yang Limin Language, the following examples are the sixteenth natural section of the text My Brother Maheegun in the second book of textbooks[4].This sentence he will take her for wild on life, hunt for her. This is the way to protect the planned life of creator. No man can change it. "This kind of text like choking, teachers can't only remain in the surface of the language symbol, but also should be further more. Here the term creator Shao Yeye refers to the Creator - God ye yuan in the wild. In the eyes of Westerners, the world is created by God. A good understanding of the deep cultural connotation of the language symbol can't be to understand the meaning of the author; the author is unable to transfer the cultural consciousness.

\section{B. And text related culture}

The scope of text related culture is very extensive, and the writer thought writing methods related to emotional topic belong to the cultural category. Teachers enable students to better understand the text, feel the charm of the target language, and the emotional resonance with the author through all-round and multi-dimension introduction. For example, the text of "say yes" in the second book of the fifth unit, teachers can import African American long history of humiliation, the struggles and hardships of free and democratic way and can involve the text associated with the hut of literary works Yethom uncle, American Society of the Ku Klux Klan and American Independent War. Through decisive introduction of this rich cultural knowledge, broaden students' horizons; stimulate students' interest in learning, so as to better understand the purpose of the text. Again, in the book 4 unit 2, the lesson of "waiting for the police" can be a thorough introduction to Sherlock Holmes mystery novel, Edgar Allan Poe's works and Chinese detective characters Di Renjie and detective stories. In the text "thinking as a hobby" in the first unit of the fourth book , cultural introduction can be involved in the domestic and foreign well-known thinker Confucius, Plato, Aristotle, Isaac Newton, Charles Darwin, Marx, Immanuel Kant who make their great contribution to the scientific development of human society. However, culture introduction and text doesn't mean occupying a lot of time of the class to associate with the text content or chat random and wantonly, the teacher should systematically guide students to understand text related cultural content. In order to better understand the article, then gradually transition to the target culture consciousness, this process throughout the whole teaching process from the beginning to the end, found in the actual teaching, cultural introduction into appropriate, active in the classroom atmosphere, stimulate the students interest in learning, broaden the horizons of students, mobilize the enthusiasm of the students, enrich the students' knowledge, enhance the ability to understand students' cultural sensitivity and the dual cultural background.

\section{Culture related to communication environment}

Zhang Zhanyi, the Chinese language teaching in the language of the text. The background knowledge is divided into two kinds knowledge culture and communication culture. Knowledge culture refers to a nation's economy, culture, art, law, religion, etc. Communication culture refers to two different cultural backgrounds. When human communicate the impact of the information can accurately convey the language and non-linguistic factors. In the process of communication, if we do not understand the culture of communication, it may cause errors or misunderstanding[5]. Therefore, in classroom teaching, communicative language and the introduction of knowledge and culture are equally important. The teaching of 
communicative culture and the introduction of communication can be from the daily life of the party. In the classroom, the teacher can't only teach the students Chinese language awareness and the characteristics of the form, but also teach the western customs, the differences between English and Chinese thinking habits, etiquette, word association and word culture, different connotation and so on. For example, the word hospital has the cultural connotation in English. Such as the hospital, restroom, landlord, husband, etc. The teacher can load the third volumes in the text of Why History Disagree of the cultural connotation of teaching, so students can better understand and master the project Language. Furthermore, in cross-cultural communication, it is also on the English taboo. Industry beginners import important content. For example, the hospital in the first volume of second units, in the lesson "Home Going", you can tell the students about the West greetings. In different ways, communication should not involve personal content and so on.

\section{INTRODUCTION OF CULTURE IN COLLEGE ENGLISH INTENSIVE READING THROUGH}

College English intensive reading course is one of the compulsory courses in colleges and universities opened for non-English major students. How to make use of the intensive reading course to introduce cultural knowledge is more important. Text explaining of Intensive reading, is generally classified as pre-class preparation, class lectures and class review three parts, teachers can explain cultural knowledge through the three parts.

\section{A. Preview}

On College English intensive reading class learning, class is very important. Comparing the College English textbooks with high school English textbooks, the number of words has increased a lot, before the lesson students will be asked to arrange the related work of culture. In the new edition of College English integrated course published by Shanghai Foreign Language Press, for example, the theme of the first and second units are Learning Ways and Chinese Learning. Style"[6].The author tells the story of his knowledge in China, and makes a comparison between Chinese and western educational methods. So to the students in the preparation of homework, you can let the students find out what is the difference between Chinese and Western education. Students can find the relevant information from the network and library, and to allow students to write about the Chinese and western educational methods of the article, the text is not limited. Write articles is one aspect, but also students can be divided into different groups, the data will be made courseware, in the classroom to let student groups tell the difference between Chinese and Western education. Through such job, you can improve students learning interest in the unit, and let students actively participate in the process of understanding the differences between Chinese and Western culture.

\section{B. Class explanation}

Students have accumulated in the class under the lessons of the similarities and differences between Chinese and western education knowledge, but as a result of the way students get information, the knowledge may be somewhat one-sided[7].So, in the class when the teacher can target to correct the students' misunderstanding of collected information. An introduction part of the Howard Text, said Gardner a, Professor of education at Harvard University. If the teacher only introduce Harvard University as a noun and slid over other background information, students will remember only the spelling of this university. Teachers can tell about the background knowledge of the Harvard University, of course, with the help of video, courseware. To give students an intuitive impression, teacher can compare it with Cambridge, University of Oxford. This will not only allow students to understand the text related cultural background knowledge, but also to stimulate motivation to learn. It is not just a word; any word in the text that appears in the text can be extended. This requires teachers to have a considerable sensitivity, and always keep in mind the language of learning and culture.

\section{Lessons under review}

The review is still to be done by the students themselves. Because the theme of this unit and life are closely related, so let the students review the text words, sentence patterns and the structure of the article, you can let the students arrange a paper on the Chinese and Western education. Students have preliminary understanding of text through the preview before class, and further understanding through the explaining of teacher in the class. In the course of the lesson, you can write an essay on the content of this unit by thinking and writing[8].The author does not suggest that teachers give students the arrangement of the four level of English only 150 words. The author thinks, let the student have the interest of study to practice every day. The learning style of small composition is old-fashioned and more meaningful, but students in writing long articles more can find where their own problems are. Through the class review, students can have a more profound understanding of the text related cultural knowledge.

\section{CONCLUSION}

Culture plays an important role in language learning. The teacher should precede different aspects: the preview before class in the College English intensive reading class, in class lectures and class review and do a good job in introducing the corresponding culture into the work, and take effective measures to let the culture run through them, in order to get a better teaching effect.

\section{REFERENCES}

[1] Sapir, E Language: An Introduction to the Speech[M].New York: Harcourt Brack and Company, 1921.

[2] Lado, D.A. Linguistics in Language Teaching[M].London: Edward Ltd, 1972.

[3] Byram, M-Cultural Studies in Foreign Language Education IMI. Clevedon and Philadelphia: Multilingual Matters,1989.

[4] Cal, G. Beyond Bad Writing: Teaching English to Chinese ESL Students, Paper presented at the College Composition and Communication Conference, San Diego, March 1993 
[5] Richards J C. Approaches and Methods in Language teaching [M]. Foreign Language Reaching and Research Press \& Cambridge University Press,1993

[6] Cal, G.Beyond Bad Writing:Teaching English to Chinese ESL Students, Paperpresented at the College Composition and Communication Conference, San Diego,March1993.
[7] Richards J C. Approaches and Methods in Language teaching[M]. Foreign LanguageReaching and Research Press\&Cambridge University Press, 1993

[8] Seelye. H. N. Teaching Culture: Strategies for Foreign Languag [M]. Lincolnwood:National Textbook Company, 1984. 